\title{
PENERAPAN PENGABDIAN KELOMPOK PETERNAKAN PADA WANITA TANI DESA PINAPALANGKOW KECAMATAN TARERAN PROVINSI SULAWESI UTARA.
}

\author{
Jein Rinny Leke ${ }^{1}$, Florencia.N Sompie ${ }^{2}$, Linda Tangkau ${ }^{1}$, Wapsiaty Utiah, ${ }^{1}$ Lentji R Nganagi ${ }^{1}$ \\ ${ }^{1}$ Jurusan Produksi Ternak,Fakultas Peternakan. Universitas Sam Ratulangi \\ 2 Jurusan Nutrisi dan Makanan Ternak, Fakultas Peternakan .Universitas Sam Ratulangi \\ *Penulis Korespondensi, Jein Rinny Leke,,Jurusan Produksi Ternak, Universitas Sam Ratulangi Manado 95115. \\ Email : rinileke@unsrat.ac.id
}

\begin{abstract}
ABSTRAK
Kegiatan pengabdian ini dilaksanakan berdasarkan permasalahan kelompok wanita tani Desa Pinapalangkow yang kurang memanfaatkan lahan pekarangan, bahan baku lokal sebagai pakan, kurang memanfaatkan pasca panen ayam buras dalam bentuk pembuatan nugget ,bakso dan kripik ceker ayam, kurang melakukan kelompok kewirausahaan. Tujuan pengabdian ini adalah untuk memberikan motivasi dan keilmuan praktis, sehingga mudah dilaksanakan oleh kelompok wanita Bougenville dan Alloevera Desa Pinapalangkow yaitu memberi sosialisasi dan penyuluhan produk pasca panen beternak ayam buras, demonstrasi kegiatan pembuatan nugget ayam dan bakso, kegiatan kewirausahaan. . Metode pengabdian digunakan adalah Participatory Rural Apraisal (PRA) yaitu suatu Metode pendidikan kepada masyarakat melalui penyuluhan, pelatihan, dan demplot. Metode ini dipilih karena PRA memiliki kelebihan diantaranya keterlibatan aktif masyarakat (sebagai subjek), dan penerapan aplikasi teknologi . Berdasarkan hasil pengabdian dapat disimpulkan bahwa upaya yang dilakukan oleh wanita tani Desa Pinapalangkow bahwa : 1). Memelihara ayam buras skala usaha rumah tangga. 2). Penyuluhan pembuatan Nugget dan Bakso. 3). Pemenuhan protein hewani bagi anak anak di Desa Pinapalangkow melalui konsumsi ayam buras baik daging maupun telur. 4). Membuat anggaran keuntungan melalui kelompok beternak ayam buras skala usaha rumah tangga. Kesimpulan : Kegiatan tim pengabdian dapat menciptakan lapangan pekerjaan bagi perempuan Desa Pinapalangkow,Kecamatan Tareran Kabupaten Minahasa Selatan Provinsi Sulawesi Utara, Kegiatan ini dapat memberikan sebuah wawasan baru bagi para perempuan dalam hal wirausaha, dengan memanfaatkan sumber daya manusia, melalui pelatihan pembutan Nugget dan bakso yang hyginies, Kegiatan ini dapat meningkatkan gizi bagi anak anak dan perekonomian di Desa Pinapalangkow
\end{abstract}

Kata Kunci: Kelompok wanita, Ayam buras.

\section{PENDAHULUAN}

\section{Analisis Situasi}

Desa Pinapalangkow merupakan salah satu dari 9 desa di wilayah Kecamatan Suluun Tareran dengan Luas \pm 850 hektar ,jumlah penduduk 1039 jiwa. Desa Pinapalangkow merupakan Desa Pertanian. Jumlah kepemilikan ternak hasil pra Survey dengan Hukum Tua Desa yaitu Kepemilikan Ayam/itik adalah 415 ekor, sapi 49 ekor, babi 215 ekor . Desa ini memliki potensi besar didalam sector pertanian (Agribisnis). Hal ini sangat wajar karena sumberdaya alam yang tersedia di desa tersebut sangat menunjang terhadap keberlangsungan usaha tani yang dijalankan oleh petani. Lahan sebagai sumberdaya alam yang penting didalam kegiatan usaha tani adalah tersedia cukup luas di Desa Pinapalangkow. Terdapat seluas \pm 550 hektar lahan kebun , 100 hektar lahan sawah, lahan untuk ladang.tanah huma sekitar 200 hektar. Desa Pinapalangkow terdapat kelompok tani Bougenville dan Kelompok Tani Aloevera. Kelompok ini terdiri dari ketua, sekertaris dan bendahara dan 10 orang anggota. Salah satu program yang lama dijalankan oleh kelompok Wanita Bougenville dan Kelompok Wanita Tani Aloevera melakukan pertemuan sekali 
dalam seminggu. Kegiatannya saat ini lebih terbatas pada kegiatan arisan setiap minggu dan kegiatan sosial masyarakat dimana proses perkawinan melakukan "Program Mapalus" berupa pemberian ayam kampung, telur, beras, rempah rempah untuk kebutuhan acara perkawinan. Sebagian wanita yang tergabung dalam kelompok ini adalah ibu rumah tangga yang tidak mempunyai pekerjaan tetap. Sebagian ibu rumah tangga membantu suami dalam melakukan proses produksi usaha tani, sebagai pedagang bahkan buruh tani, Kegiatan ini dilakukan ibu rumah tangga untuk membantu suami dalam memperoleh pendapatan. Pendapatan yang diperoleh dialokasikan untuk pengeluaran konsumsi rumahtangga. Banyaknya kebutuhan rumahtangga tersebut menyebabkan pendapatan yang diperoleh kepala keluarga tidak mencukupi dan pemenuhan gizi keluarga sangat rendah akibat dari biaya tidak tercukupi. Kelembagaan juga sebagai unsur penting lainnya yang menunjang pembangunan ekonomi pedesaan beberapa telah terbentuk dengan baik. Desa Pinapalangkow memiliki beberapa lembaga ekonomi penting diantaranya adalah kelompok tani serta gabungan kelompok tani. Kelompok tani di Desa Pinapalangkow adalah Kelompok Wanita Alloevera dan Boegenville. Namun demikian potensi potensi tersebut belum mampu meningkatkan kesejahteraan petani dan masyarakat pada umumnya. Menurut analisis kami terdapat beberapa faktor yang mengakibatkan hal tersebut terjadi, diantaranya adalah :

1. Masih rendahnya kualitas sumber daya manusia. Kualitas sumber daya manusia berbanding lurus dengan tingkat pendidikannya. Pada umumnya petani yang berada di Desa Pinapalangkow adalah lulusan SD dan SMP. Rendahnya tingkat pendidikan ini berdampak pada mutu pengetahauan mereka khususnya yang terkait dengan usaha pelatihan pembuatan nugget ayam dan stick susu, (usaha berbasis bisnis), tingkat adopsinya terhadap inovasi serta proses pengambilan keputusan terutama yang berkaitan dengan kegiatan usaha berbasis bisnis.Selain itu, belum berkembangnya teknologi pengoalahan pelatihan pelatihan teknologi hasil ternak dikalangan petani menyebabkan petani belum mendapatkan nilai tambah atas hasil pertaniannya serta berkurangnya jam kerja petani beserta keluarganya.

2. Kurang serta belum diketahuinya, akses terhadap pengetahuan pengolalan teknologi hasil,. Banyak diantara penduduk yang terkandala pengembangan usaha lebih lanjut.

Pemberdayaan mempunyai makna harafiah membuat sesoarang dan kelompok berdaya, istilah lain untuk memberdayakan adalah penguatan (empowerment). Pemberdayaan pada evaluasi dari solusi yang ditentukan. Dengan meningkatnya kemandirian perempaun dalam bidang ekonomi akan meningkatnya kemandirian perempuan dalam bidang ekonomi akan meningkatkan pula penghasilan dan kesejahteraan keluarganya, yang selanjutnya akan mampu mempengaruhi perempuan lain agar mau ikut ambil bagian dalam peningkatan ketrampilan dan pengetahuan, sehingga akhirnya mampu pula meningkatkan kesejahteraan masyarakat ( Indriyati.dkk .2013). Dengan menerapkan model pendekatan pemberdayaan perempuan desa melalui pendekatan sosiokultural, ekonomi dan lingkungan hidup dapat diharapkan perempuan miskin mampu mengendali dirinya sebagai manusia yang utuh dan menunjang nilai nilai kemanusiaan, dan dengan pendekatan cultural dapat diketahui faktor faktor budaya yang mendukung perubahaan. Pendekatan ekonomi ini diharapkan perempuan dapat meningkatkan penghasilan nya melalui usaha ekonomi produktif untuk memenuhi kebutuhan hidup pokok yang layak. Usaha ternak ayam kampung sebagai usaha ternak rakyat diharapkan mampu meningkatkan pedapatan dan ketahanan pangan . Ketahanan pangan tercipta bila sudah ada kedaulatan pangan. Kegiatan ekonomi produktif yang dapat dikembangkan pada kelompok wanita yaitu pembuatan nugget,kripik caker ayam dan dishplay produk. Nugget adalah suatu bentuk produk daging giling yang dibumbu, kemudian diselimuti oleh perekat tepung (batter), pelumuran tepung roti (breading), lalu dibekukan untuk mempertahankan mutunya selama penyimpanan. Produk nugget dapat dari daging kelinci, sapi,ayam,ikan dan lain lain, tetapi yang popular 
Adapun beberapa metode yang digunakan dalam kegiatan ini adalah : metode demontrasi dengan media leaflet dan video.

Langkah - langkah yang dilakukan dalam kegiatan :

a) Memberitahukan kepada kelompok tani alloevera dan boegenvile, untuk pelaksanaan pengabdian. Bersama tim fapet Unsrat dan kelompok tani sepekat melaksanakan kegaiatn.

b) Tim pengabdian Fapet Unsrat sebagai coordinator : Dr.Ir Jein Rinny Leke MP, sebagai dosen kepakaran dibidang Unggas memberikan materi kegiatan pada kelompok tani, kemudian dilanjutkan dengan demontrasi pembuatan Nugget, Bakso, kripik ceker ayam.

\section{Tujuan dan Manfaat Kegiatan}

Sesuai dengan rencana kegiatan, maka luaran yang dihasilkan atau ditargetkan dalam kegiatan pengabdian pada masyarakat ini adalah :

a) Melatih para kelompok Wanita Bougenville dan Kelompok Wanita Tani Aloevera yang tergabung dalam kelompok tani di Desa Pinapalangkow .

b) Meningkatkan pengetahuan wanita tani dalam pembuatan nugget dan bakso

c) Meningkatkan pengetahuan kewirausahaan wanita tani.

\section{METODE PELAKSANAAN}

\section{Sasaran kegiatan}

Yang menjadi sasaran pelaksanaan kegiatan pelatihan ini adalah para kelompok wanita tani Desa Pinapalangkow kecamatan Tareran Kabupaten Minahasa Selatan .Provinsi Sulawesi Utara.

\section{Lokasi kegiatan}

Lokasi kegiatan dilaksanakan Di kelompok wanita Alloevera dan Bougenvile Kabupaten Minahasa Selatan Metode yang digunakan :

\section{HASIL DAN PEMBAHASAN}

Kegiatan yang telah dilakukan dalam mencapai tujuan pengabdian kepada masyarakat ini adalah:

1.Persiapan . Mengurus surat tugas dari LPPM Universitas Sam Ratulangi.Manado. Melakukan koordinasi dengan Hukum Tua Desa Pinapalangkow Bapak Fery Liando, serta perangkat Desa Pinapalangkow.

2.Pelaksanaan.Kegiatan penyuluhan di laksanakan pada hari Jumat, 5 Juli 2019 dari jam 09.00 Wita sampai 15.00 Wita. Kegiatan berupa penyuluhan dan demonstrasi pembuatan nugget, bakso dan kripik ceker ayam.

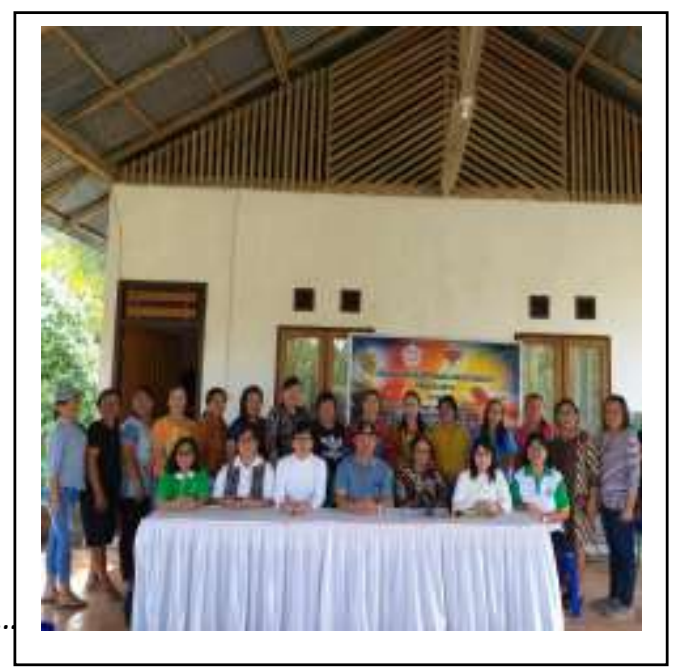


Gambar 1.Tim Fapet Unsrat dan Hukum Tua Desa Pinapalangkow bersama kelompok.

\section{Penyuluhan}

Adapun hasil kegiatan yang diperoleh adalah sebagai berikut : Penyuluhan dilakukan terhadap anggota kelompok usaha Bougevenllie dan Alloevera dengan tujuan mengubah perilaku sumberdaya anggota kelompok kearah yang lebih baik. Beberapa falsafah penyuluhan adalah : (1) Penyuluhan menyandarkan programnya pada kebutuhan petani: (2) penyuluhan pada dasarnya adalah proses pendidikan untuk orang dewasa yang bersifat non formal,(3) penyuluhan bekerjasama dengan organisasi lainnya untuk mengembangkan individu, kelompok dan bangsa

Materi Penyuluhan:

1. Penguatan kelembagaan

2. Teknologi hasil : Pembuatan Chicken Nugget, Display Produk

3. Analisis cash Flow

Kegaiatan penyuluhan dilakukan bagi masyarakat peternak ayam buras yang ada di Desa Pinapalangkow dengan membuat Leaflet dan brosur.

\subsection{Pelatihan}

Pelatihan dilakukan setelah penyuluhan masyarakat peternak ayam buras selanjutnya dilakukan pelatihan bagi anggota kelompok Wanita Bougenville dan kelompok wanita Alloevera sasaran berdasarkan Tabel.1. Pelatihan melibatkan beberapa mahasiswa .

A.Kelompok Wanita Bougenville Desa Pinapalangkow

Dalam pembuatan kripik ceker ayam ada setidaknya delapan tahapan yang harus dilewati untuk mendapatkan produk yang berkualitas. Yang pertama yaitu :

1. Penyeleksian dan pencucian, yaitu : dengan memilih bahan baku utama yang gemuk dan tidak cacat, baik berupa luka sayatan maupun jenis penyakit lainnya.

2. Perendaman dalam air kapur dengan konsentrasi $2 \%$ dari berat ceker ayam yang akan direndam selama 1-3 jam.

3. Perebusan selama beberapa saat sampai ceker ayam agar lunak kemudian dilakukan penirisan

4. Pengulitan dengan mengupas dari bagian jari terlebih dahulu secara hati hati agar bahan tidak hancur,

5.Pemberian bumbu dan penjemuran kemudian dilakukan penggorengan, kemudian didiamkan malam,penggorengan, pengemasasan.

\section{B.Kelompok Wanita Alloevera Desa Pinapalangkow}

Nugget adalah suatu bentuk produk olahan daging yang terbuat dari daging giling yang dicetak dalam bentuk potongan empat persegi dan dilapisi dengan tepung berbumbu (battered dan breaded). Badan Standarisasi Nasional (BSN) (2002) pada SNI.01-6638-2002 mendefinisikan nugget ayam sebagai produk olahan ayam yang dicetak, dimasak, dibuat dari campuran daging ayam giling yang diberi bahan pelapis dengan atau tanpa penambahan bahan makanan lain dan bahan tambahan makanan yang diperbolehkan.( Tisnginiyati K.N. 2013).Pelatihan pembuatan Chicken Nugget sebagai berikut Menyiapkan bahan dan alat seperti penggiling daging,pisau,langseng, talenan, cetakan,loyang,pemanas, bahan : daging ayam, bawang bombay, roti tawar tanpa kulit, tepung tapioca, susu segar, penyedap rasa, telur,merica, garam, air, bahan pelapis : tepung terigu, tepung kanji,,bumbu +air matang,tepung roti halus dan kasar berwarna masing masing, pisahkan daging ayam dari tulang,lemak dan kulit,potong daging ayam kecil kecil,giling dengan meat grinder bersamaan dengan bumbu bumbu,campur hingga merata,cetak adonan nugget kedalam loyang atau wadah lainnya, masukkan adonan kedalam langseng dan kukus selama 45 menit,dinginkan dan masukkan 
kedalam mesin pendingin selama semalam,iris adonan sesuai selera, masukkan irisan nugget kedalam kocokan putih telur dan gulirkan diatas campuran tepung roti dan tepung panir,goreng menggunakan api sedang hingga matang

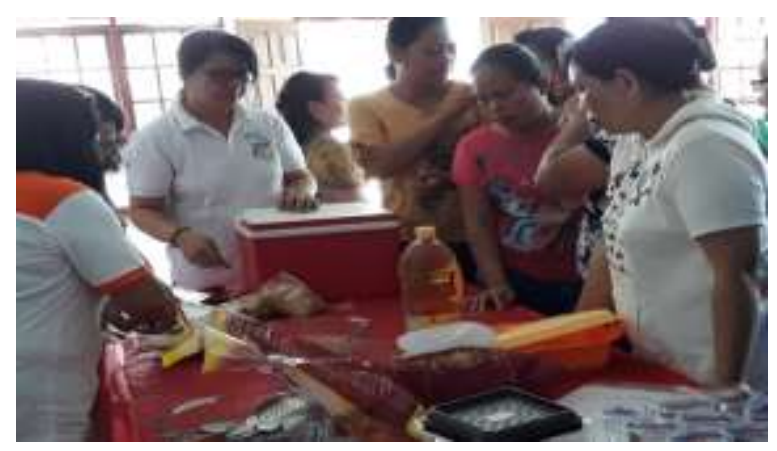

Gambar 2. Kegiatan pelatihan pembuatan nugget/bakso.

Pemberdayaan dikelompok wanita Desa Pinapalangkow meliputi proses sosialisasi dan pelatihan agar terjadi perubahaan pola pikir (sumber daya manusia ) bagi perempuan desa Pinapalangkow dan meningkatnya pendapatan keluarga, serta peningkatan gizi anak anak dipedesaan. Hal ini menunjukkan bahwa pemberdayaan masyarakat ini, dapat dilakukan untuk masyarakat khususnya perempuan Desa Pinapalangkow yang memiliki pendidikan dasar yang kurang. Keterlibatan perempuan secara maksimal dalam tim perlu dilakukan karena program diharapkan dapat memberdayakan perempuan (Saugi \& Sumarmo ,2015). Pemberdayaan dikelompok wanita Alloevera dan Bougenville dibentuk DiDesa Pinapalangkow, Kecamatan Tareran Kabupaten Minahasa Selatan bertujuan untuk meningkatkan potensi sumber daya manusia perempuan Desa Pinapalangkow dan peningktan gizi anak anak Desa Pinapalangkow. Pemberdayaan dalam Adi (2012; 213) Hogan menjelaskan bahwa dalam konteks kesejahteraan sosial pemberdayaan terkait dengan upaya meningkatkan taraf hidup masyarakat dari suatu tingkatan ke tingkatan yang lebih baik. Tentunya dengan mengkaji faktor-faktor yang menyebabkan suatu komunitas menjadi kurang beraya (depowerment).
Kegaiatan sosialisasi didampingi oleh Hukum tua Desa Pinapalangkow Bapak Ferry Londo bersama Ketua Dasa Wisma Desa Pinapalakow Ny Evelin Londo- Londolintang Spt. Hasil evaluasi kegiatan setelah dilakukan monitoring lapangan bahwa perempuan kelompok wanita Boegenviile dan Alloevera sudah melaksanakan kegiatan pembuatan nugget,bakso dan kripik ceker ayam dalam kegiatan kegiatan jualan bakso dan nugget skala usaha kecil, di sediakan pesta-pesta, maupun diberikan kepada anak anak untuk peningkatan gizi anak anak Desa Pinapalangkow. Peningkatan pendapatan melalui program kewirausahaan desa yang dilakukan oleh kelompok perempuan Desa. Pendapatan keluarga belum cukup, tetapi upaya kegaitan tim Program Kreartivitas Masyarakat oleh Fakultas Peternakan Universitas Sam Ratulangi untuk dapat meningkatkan pengetahuan kelompok perempuan dan peningkatan pendapatan.

Perempuan mengemban peran penting dalam keluarga. Perempuan menciptakan kehidupan. Perempuan sebagai tiang pondasi bagi sebuah keluarga bahkan masyarakat. Perempuan yang pintar mampu menghasilkan keturunan yang berkualitas juga, perempuan yang memiliki pengetahuan yang luas, mampu memberikan dukungan bagi suaminya dan mampu berkontribusi didalam kehidupanbermasyarakat. (Gevia N.I.D,2017)

\section{KESIMPULAN DAN SARAN}

Dari uraian diatas maka dapat ditarik sebuah kesimpulan sebagai berikut :

a.Kegiatan Tim Program Kreativitas Masyarakat dapat menciptakan Lapangan pekerjaan bagi perempuan Desa Pinapalangkow,Kecamatan Tareran Kabupaten Minahasa Selatan Provinsi Sulawesi Utara. .

b.Kegiatan ini dapat memberikan sebuah wawasan baru bagi para perempuan dalam hal wirausaha, dengan memanfaatkan sumber daya manusia, melalui pelatihan pembutan Nugget dan bakso yang hyginies.

c.Kegiatan ini dapat meningkatkan Gizi bagi anak anak dan perekonomian di Desa Pinapalangkow.

\section{SARAN}


pangan lokal.Jurnal Pendidikan dan

Kegiatan ini Program Kreativitas Masyarakat yang dilakukan oleh Universitas Sam Ratulangi, sangat menunjang kelompok perempuan dan anak di Desa, sehingga diharapkan kegiatan ini dapat berjalan terus, dan dapat ditingkatkan

\section{UCAPAN TERIMAKASIH}

Terimakasih diucapkan kepada Hukum Tua Desa Pinapalangkow, Kecamatan Tareran Provinsi Sulawesi Utara dan Ketua kelompok Wanita Alloevera dan Boegenville Desa Pinapalangkow. Terimakasih kepada LPPM Unsrat yang mendanai kegiatan Program kreativitas Mahasiswa Tahun 2019 melaui dana PNPB Unsrat.

\section{DAFTAR PUSTAKA}

Adi, Isbandi Rukminto. 2012 (Edisi Revisi). Intervensi Komunitas: Pengembangan Masyarakat ssebagai Upaya Pemberdayaan Masyarakat. Jakarta: PT RajaGrafindo Pers. Hardi. 2015. Membuat Chicken Nugget.Buku Pinta Peternakan Jilid II. Balai Besar Pelatihan Peternakan Batu.

Indriyati, dan Nugrajani . 2013. Strategi Penaggulangan Kemiskinan Melalui Program Pemberdayaan Perempuan (Studi Empiris Pengentasan Kemiskinan di Kabupaten Sleman). Jurnal Ilmiah PADMA Sri Kresna. Universitas Widya Mataram Yogyakarta.

Gevia Nur Isna Deraputri,. R. Nunung Nurwati, Risna Resnawaty.2017. Pemberdayaan Perempuan melalui Program Pendidikan kewisausahaan Kreatif Terpadu Untuk Perempuan,Anak dan kelaurga oleh Organisasi World Muslimah Fondation Di kampung Muka Jakarta Utara. Prosiding dan Pengabdian Kepada masyarakat.Vol.3(3):292:428.

Saugi, Sumarmo.(2015). Pemberdayaan Perempuan melalui pengolahan bahan pemberdayaan Masyarakat. 2355-1615 .

Tisnginiyati K.N.2013 . Pengaruh subsitusi Nangka Muda (Artocarpus Heterophyllus LMK) Terhadap Kualitas Organoleptik Nugget Ayam. Food Science and Culinary Education Journal. Vol .2 (1) 19. 